\title{
Analisis Kuantitatif Ketidaklengkapan Pengisian Resume Medis Berdasarkan Program Quality Assurance (Suatu Studi di Rumah Sakit Delta Surya Sidoarjo)
}

\author{
Tri Murni $\mathrm{M}^{1}$, Ina Suhartina ${ }^{2}$, Indah Dwi $\mathrm{S}^{3}$ \\ Sekolah Tinggi Ilmu Administrasi Malang ${ }^{1,2,3}$ \\ inasuhartina57@gmail.com²
}

\begin{abstract}
Diajukan 4 Maret 2019 Diperbaiki 10 Mei 2019 Diterima 28 Mei 2019
ABSTRAK

Latar Belakang: Rumah sakit menyelenggarakan pelayanan kesehatan perorangan secara paripurna melalui pelayanan rawat jalan, rawat inap, dan gawat darurat. Semua aspek pelayanan harus sesuai standar khususnya bagian rekam medis sebagai acuan untuk menentukan tindakan kepada pasien. Kelengkapan pengisian berkas rekam medis sangat penting untuk menunjang kualitas pelayanan. Berkas yang tidak lengkap akan berdampak pada pengambilan tindakan terhadap pasien sehingga kualitas pelayanan kesehatan dapat menurun.

Tujuan: Penelitian ini bertujuan untuk menganalisis kelengkapan pengisian resume medis pasien menggunakan program Quality Assurance.

Metode: Jenis penelitian kasus ini menggunakan deskriptif kuantitatif. Metode pengumpulan data yaitu observasi dan wawancara.

Hasil: Hasil penelitian ini menunjukkan persentase rata-rata kelengkapan resume medis pada bulan Januari - April 2018 sebesar 96\%, yang di dapatkan dari pehitungan kelengkapan pengisian resume medis pada bulan Januari sebesar $97 \%$, bulan Februari 94\%, serta bulan Maret dan April sebesar $97 \%$. Pencapaian mutu dalam langkah kegiatan Quality Assurance telah mencapai persentase kesesuaian sebesar $97,1 \%$ dan ketidaksesuaian sebesar 2,9\%.

Kesimpulan: Pelaksanaan proses kegiatan Quality Assurance pada pengisian resume medis pasien belum maksimal dan kurang dari standar angka yang telah ditetapkan. Maka dari itu, perlu dibuatkan pedoman mutu untuk meningkatkan Quality Assurance di Rumah Sakit Delta Surya Sidoarjo.
\end{abstract}

Kata Kunci: resume medis; quality assurance; rumah sakit

\section{ABSTRACT}

Background: Hospital is organizes individual health services in a comprehensive manner that provides outpatient services, inpatient care, and emergency services. All aspects of the service must be in accordance with established standards. Especially in the medical record section, which is a reference for determining actions for patients who are on treatment. The completeness of filling in the medical record file is very important to support the quality of hospital services. Incomplete medical record files will cause problems in patients care, which will decrease the quality of health services

Objective: This study aims to analyze the completeness of filling in medical resumes of patients using the Quality Assurance program.

Method: This type of research for this case used descriptive quantitative method. While for the data collection method that is done is observation and interview or interview.

Results: This study show the percentage of average medical resume in January - April 2018 amounted to $96 \%$, which was obtained from the calculation of completeness of medical resumes in January at 97\%, February at $94 \%$, and March and April at $97 \%$. While the achievement of quality in the steps of Quality Assurance activities has reached the percentage of conformity of $97.1 \%$ and a non-compliance of $2.9 \%$.

Conclusion: The implementation of the Quality Assurance activity process on filling the patient's medical resume has not optimal and is less than the predetermined standard number which should have reached $100 \%$. Therefore, quality guidelines need to be made to improve Quality Assurance at Delta Surya Hospital Sidoarjo.

Keywords: medical resume; quality assurance; hospital 


\section{PENDAHULUAN}

Rumah sakit merupakan salah satu infrastruktur pemerintahan yang berfungsi melakukan upaya kesehatan dasar atau kesehatan rujukan dan atau upaya kesehatan penunjang yang bersifat kompleks, padat pakar, dan padat modal (Suryantara, 2015). Kompleksitas ini dikarenakan pelayanan rumah sakit terdiri atas berbagai fungsi pelayanan, pendidikan, penelitian, serta mencangkup berbagai tingkatan maupun jenis disiplin ilmu.

Kondisi tersebut dikarenakan banyaknya aspek-aspek dalam rumah sakit baik secara administratif maupun praktik pelayanan kesehatan yang melibatkan sumber daya manusia dari berbagai bidang, mulai dari pendaftaran, pencatatan, sampai pelayanan kesehatan yang diberikan kepada pasien. Seluruh aspek tersebut harus dipikirkan secara matang dan dikerjakan oleh sumber daya manusia yang ahli dibidangnya agar kualitas dan mutu rumah sakit dapat terjaga (Hatta, 2014).

Terdapat berbagai proses pelayanan kesehatan di rumah sakit. Salah satu bagian penting dari keseluruhan proses pelayanan kesehatan adalah bagian rekam medis. $\mathrm{M}$ e $\mathrm{n} \mathrm{u} \mathrm{r} \mathrm{u} \mathrm{t} \mathrm{P} \mathrm{E} \mathrm{R} \mathrm{M} \mathrm{E} \mathrm{N} \mathrm{K} \mathrm{E} \mathrm{S}$ No.269/MENKES/III/2008 tentang rekam medis(Menkes, 2008), rekam medis merupakan berkas yang memuat catatan dan data terkait identitas pasien, hasil pemeriksaan, riwayat pengobatan yang telah diberikan, serta tindakan dan pelayanan lain yang telah dilakukan kepada pasien. Rekam medis tersebut memuat keterangan, baik secara tertulis ataupun yang terekam terkait identitas, anamnesis, penentuan fisik, laboratorium, diagnosis segala pelayanan dan tindakan medik yang dilakukan kepada pasien, serta pengobatan baik yang rawat inap, rawat jalan, maupun rawat darurat.

Rekam medis memiliki nilai medis karena catatan tersebut digunakan sebagai acuan dalam menyiapkan tahapan pengobatan atau tindakan yang harus dilakukan kepada pasien. Pada aspek hukum, isi rekam medis menyangkut tentang adanya jaminan kepastian isi resume medis pasien itu sendiri. Ketidaklengkapan resume medis dapat memengaruhi kualitas pelayanan kesehatan suatu rumah sakit dikarenakan dokumen resume medis tersebut digunakan sebagai dasar pengobatan selanjutnya untuk pasien, maka informasi riwayat medis dari dokumen resume medis yang tidak lengkap akan mengakibatkan pengobatan tidak berjalan secaraberkesinambungan.

Dibutuhkan pengendalian dalam kegiatan pengisian dokumen resume medis dalam rangka meningkatkan mutu pelayanan, serta mengingat pentingnya resume medis untuk rumah sakit. Sebenarnya, resume medis ialah satu dari sekian bagian penting yang terdapat dalam pelayanan kesehatan di rumah sakit. Mutu rekam medis di rumah sakit memiliki andil dalam penentuan mutu pelayanan, mengingat rekam medis merupakan salah satu standar yang wajib terpenuhi oleh rumah sakit jika ingin mendapatkan predikat akreditasi.

Tinjauan kelengkapan resume medis pasien sebagai sumber data untuk penilaian mutu pelayanan kesehatan di rumah sakit adalah salah satu kegiatan dari Program Menjaga Mutu (Quality Assurance), yaitu penilaian mutu yang diberikan setelah pelayanan kesehatan diberikan.

Quality Assurance dalam rumah sakit merupakan salah satu faktor penting dan fundamental dan wajib terpenuhi khususnya bagi manajemen rumah sakit itu sendiri, sebab imbas dari Quality Assurance menentukan kualitas rumah sakit. Untuk rumah sakit, adanya Quality Assurance yang baik akan menjadikan rumah sakit bisa bersaing dan tetap bertahan dalam hati pasien. Untuk praktisi medis, selain terikat dengan standar profesinya, keberadaan Quality Assurance menuntut para praktisi medis memiliki ketelitian dan kehati-hatian ekstra dalam menjaga mutu pelayanannya. Bagi pemerintah, adanya Quality Assurance dapat digunakan 
sebagai acuan dalam memutuskan kebenaran dalam kasus yang terjadi di suatu rumah sakit.

Quality Assurance merupakan suatu cara dalam peningkatan mutu pelayanan yang dilakukan secara continua atau berkelanjutan. Oleh sebab itu, upaya tersebut dapat digambarkan sebagai suatu siklus Quality Assurance dan semua langkah yang terdapat dalam siklus Quality Assurance berulang dan berkesinambungan serta tidak pernah berhenti, siklus tersebut yaitu:

1. Perencanaan,

2. Menyusun Standar,

3. Mengomunikasikan Standar,

4. Monitoring Mutu,

5. Identifikasi Masalah dan Prioritas,

6. Menetapkan Masalah,

7. Identifikasi Siapa yang Akan Mengerjakan Masalah (Memilih Tim),

8. Analisa dan Mempelajari Masalah,

9. Memilih dan Mendesain Solusi,

10. Implementasi Solusi.

Rumah Sakit Delta Surya Sidoarjo (RSDSS) merupakan salah satu rumah sakit besar dan sering menjadi pilihan warga kota Sidoarjo. Rumah sakit ini terkenal dikalangan warga Sidoarjo sebagai rumah sakit yang memiliki proses pelayanan penggunaan BPJS yang mudah, sehingga banyak masyarakat dari latar belakang ekonomi menengah kebawah memilih untuk berobat ke Rumah Sakit Delta Surya Sidoarjo. Hasil kuesioner pra-penelitian yang diberikan kepada 50 orang yang tinggal di kota Sidoarjo secara acak (Random Sampling), menghasilkan data sebagai berikut :

\section{Berobat}

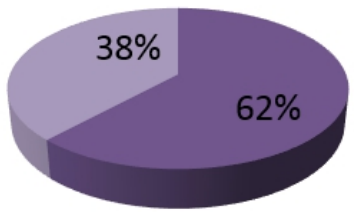

Pernah

Belum Pernah

Gambar 1. Hasil Quisoner 1

\section{Lokasi Rumah Sakit}

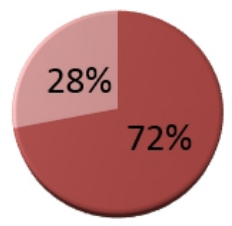

จTahu

$\checkmark$ Tidak Tahu

\section{Gambar 2. Hasil Quisioner 2}

Berdasarkan data pada gambar 1 dan 2, dapat disimpulkan bahwa Rumah Sakit Delta Surya Sidoarjo adalah Rumah sakit yang sangat populer dikalangan masyarakat Sidoarjo. Alasan peneliti tertarik untuk meneliti kelengkapan pengisian resume medis menggunakan program Quality Assurance di Rumah Sakit Delta Surya Sidoarjo karena rumah sakit ini sering dikunjungi untuk berobat masyarakat.

\section{METODE PENELITIAN}

Penelitian ini menggunakan pendekatan penelitian kuantitatif. Menurut (Creswell, 2010), penelitian kuantitatif merupakan jenis metode penelitian yang dilakukan dengan tinjauan utama untuk mendeskripsikan suatu keadaan secara obyektif. Jenis penelitian ini digunakan untuk memecahkan atau menjawab permasalahan yang sedang dihadapi pada situasi tertentu. Penelitian ini dilakukan dengan menempuh langkah-langkah pengumpulan data, klasifikasi, pengolahan atau analisis data, membuat kesimpulan, dan laporan.

Penelitian ini berlokasi di Rumah Sakit Delta Surya Sidoarjo, khususnya bagian berkas rekam medis, dengan fokus penelitian adalah menganalisis kelengkapan pengisisan resume medis berdasarkan program Quality Assurance di Rumah Sakit Delta Surya Sidoarjo.

Peneliti menggunakan data primer berupa berkas resume medis pasien berjumlah 73 berkas yang diambil secara acak (random sampling) pada bulan Januari-April 2019. Metode pengumpulan data dilakukan melalui pengamatan terhadap proses pengisian resume 
medis oleh pegawai bagian rekam medis. Selain itu, peneliti juga membutuhkan data sekunder berupa bacaan-bacaan dan sumber literatur untuk menelaah hasil pengamatan yang didapatkan.

Proses selanjutnya, data dianalisis secara deskriptif menggunaan kaidah studi dokumen. Dokumentasi juga adalah aktivitas pencarian fakta atau variabel dari sumber berupa bendabenda tertulis seperti catatan, transkrip, buku, dokumen, dan sebagainya. Studi dokumen dilakukan dengan melihat berkas rekam medis terutama formulir resume medis dan buku ekspedisi yang terkait kelengkapan pengisian resume medis pasien rumah sakit.

\section{HASIL DAN PEMBAHASAN}

Berdasarkan hasil penelitian ketidaklengkapan pengisian catatan medis (KLPCM) pada bulan Januari-April 2019, terdapat beberapa item yang tercantum pada resume medis yang wajib terisi secara lengkap selama $1 \times 24$ jam. Item-item tersebut meliputi :

$\mathrm{A}=$ Identitas (Register/No. RM, Nama Pasien, Tanggal Lahir)

$\mathrm{B}=$ Tanggal MRS \& KRS, Meninggal

$\mathrm{C}=$ Anamnesis

D $=$ Hasil Pemeriksaan Fisik Waktu MRS

$\mathrm{E}=$ Diagnosis Akhir

$\mathrm{F}$ = Masalah yang Dihadapi

$\mathrm{G}=$ Pengobatan/Tindakan

$\mathrm{H}=$ Perjalanan Penyakit Selama Perawatan/Komplikasi

I = Keadaan Waktu Keluar Rumah Sakit

$\mathrm{J}=$ Prognosis/Sebab Meninggal

$\mathrm{K}=$ Follow $\mathrm{Up}$

$\mathrm{L}=$ Tanda Tangan Dokter Penanggung Jawab Pasien (DPJP)

$M=$ Nama Terang Dokter Penanggung Jawab Pasien (DPJP)

Perhitungan persentase dalam evaluasi kelengkapan serta kesesuaian langkah Quality Assurance dapat dihitung dengan rumus berikutini:
$\mathrm{P}=\frac{\mathrm{F}}{\mathrm{N}} \times 100 \%$

Keterangan:

$\mathrm{P}=$ Nilai Persentase

$\mathrm{F}=$ Angka Kesesuaian

$\mathrm{N}=$ Jumlah Nilai Total

Data evaluasi kelengkapan resume medis pada pelayanan pasien dari bulan JanuariApril 2019 menghasilkan data persentase kelengkapan sebagai berikut:

Tabel 1. Data Evaluasi Kelengkapan Resume Medis Pasien Pada Bulan Januari 2019

\begin{tabular}{|c|c|c|c|c|c|}
\hline No. & ITEM & JUMLAH & LENGKAP & $\begin{array}{l}\text { TIDAK } \\
\text { LENGKAP }\end{array}$ & $\begin{array}{c}\text { PERSENTASE } \\
\text { KELENGKAPAN }(\%)\end{array}$ \\
\hline 1. & A & 17 & 16 & 1 & $94 \%$ \\
\hline 2. & B & 17 & 17 & 0 & $100 \%$ \\
\hline 3. & C & 17 & 17 & 0 & $100 \%$ \\
\hline 4. & D & 17 & 17 & 0 & $100 \%$ \\
\hline 5. & E & 17 & 17 & 0 & $100 \%$ \\
\hline 6. & $\mathrm{~F}$ & 17 & 17 & 0 & $100 \%$ \\
\hline 7. & G & 17 & 15 & 2 & $88 \%$ \\
\hline 8. & $\mathrm{H}$ & 17 & 16 & 1 & $94 \%$ \\
\hline 9. & I & 17 & 16 & 1 & $94 \%$ \\
\hline 10. & J & 17 & 17 & 0 & $100 \%$ \\
\hline 11. & K & 17 & 16 & 1 & $94 \%$ \\
\hline 12. & L & 17 & 17 & 0 & $100 \%$ \\
\hline 13. & M & 17 & 17 & 0 & $100 \%$ \\
\hline \multicolumn{2}{|c|}{ TOTAL } & 221 & 215 & 6 & $97 \%$ \\
\hline
\end{tabular}

Berdasarkan tabel 1 diperoleh perhitungan sebagai berikut:

$\mathrm{P}=\frac{\mathrm{F}}{\mathrm{N}} \times 100 \%$

$\mathrm{P}=\frac{215}{221} \times 100 \%$

$P=0.9728=97 \%$

Hasil perhitungan menurut data KLPCM bulan Januari 2019, total kelengkapan resume medis pada poin A sampai dengan M dikatakan tidak lengkap dengan kelengkapan pengisian sebesar $97 \%$.

Tabel 2. Data Evaluasi Kelengkapan Resume Medis Pasien Pada Bulan Februari 2019

\begin{tabular}{|c|c|c|c|c|c|}
\hline No. & ITEM & JUMLAH & LENGKAP & $\begin{array}{l}\text { TIDAK } \\
\text { LENGKAP }\end{array}$ & $\begin{array}{c}\text { PERSENTASE } \\
\text { KELENGKAPAN }(\%)\end{array}$ \\
\hline 1. & A & 18 & 18 & 0 & $100 \%$ \\
\hline 2. & B & 18 & 18 & 0 & $100 \%$ \\
\hline 3. & C & 18 & 18 & 0 & $100 \%$ \\
\hline 4. & $D$ & 18 & 18 & 0 & $100 \%$ \\
\hline 5. & E & 18 & 18 & 0 & $100 \%$ \\
\hline 6. & $\mathrm{~F}$ & 18 & 13 & 5 & $72 \%$ \\
\hline 7. & $G$ & 18 & 18 & 0 & $100 \%$ \\
\hline 8. & $\mathrm{H}$ & 18 & 17 & 1 & $94 \%$ \\
\hline 9. & 1 & 18 & 17 & 1 & $94 \%$ \\
\hline 10. & $\mathrm{~J}$ & 18 & 17 & 1 & $94 \%$ \\
\hline 11. & K & 18 & 13 & 5 & $72 \%$ \\
\hline 12. & $\mathrm{~L}$ & 18 & 18 & 0 & $100 \%$ \\
\hline 13. & M & 18 & 18 & 0 & $100 \%$ \\
\hline \multicolumn{2}{|c|}{ TOTAL } & 234 & 221 & 13 & $94 \%$ \\
\hline
\end{tabular}


Berdasarkan tabel 2 diatas diperoleh perhitungan sebagai berikut:

$$
\begin{aligned}
& P=\frac{F}{N} \times 100 \% \\
& P=\frac{221}{234} \times 100 \% \\
& P=0.9444=94 \%
\end{aligned}
$$

Berdasarkan hasil perhitungan menurut data KLPCM bulan Februari 2019, total kelengkapan resume medis pada poin A sampai dengan $\mathrm{M}$ dikatakan tidak lengkap dengan kelengkapan pengisian sebesar $94 \%$.

\begin{tabular}{|c|c|c|c|c|c|}
\hline No. & ITEM & JUMLAH & LENGKAP & $\begin{array}{l}\text { TIDAK } \\
\text { LENGKAP }\end{array}$ & $\begin{array}{c}\text { PERSENTASE } \\
\text { KELENGKAPAN }(\%)\end{array}$ \\
\hline 1. & A & 20 & 19 & 1 & $95 \%$ \\
\hline 2. & B & 20 & 20 & 0 & $100 \%$ \\
\hline 3. & C & 20 & 20 & 0 & $100 \%$ \\
\hline 4. & $D$ & 20 & 20 & 0 & $100 \%$ \\
\hline 5. & $E$ & 20 & 20 & 0 & $100 \%$ \\
\hline 6. & $F$ & 20 & 20 & 0 & $100 \%$ \\
\hline 7. & G & 20 & 20 & 0 & $100 \%$ \\
\hline 8. & $\mathrm{H}$ & 20 & 19 & 1 & $95 \%$ \\
\hline 9. & I & 20 & 20 & 0 & $100 \%$ \\
\hline 10. & $\mathrm{~J}$ & 20 & 19 & 1 & $95 \%$ \\
\hline 11. & K & 20 & 16 & 4 & $80 \%$ \\
\hline 12. & L & 20 & 19 & 1 & $95 \%$ \\
\hline 13. & M & 20 & 20 & 0 & $100 \%$ \\
\hline \multicolumn{2}{|c|}{ TOTAL } & 260 & 252 & 8 & $98 \%$ \\
\hline
\end{tabular}

Tabel 3. Data Evaluasi Kelengkapan Resume Medis Pasien Pada Bulan Maret 2019

Berdasarkan tabel 3 diatas diperoleh perhitungan sebagai berikut:

$$
\begin{aligned}
& \mathrm{P}=\frac{\mathrm{F}}{\mathrm{N}} \times 100 \% \\
& \mathrm{P}=\frac{252}{260} \times 100 \% \\
& \mathrm{P}=0.9763=98 \%
\end{aligned}
$$

Hasil perhitungan menurut data KLPCM bulan Maret 2019, total kelengkapan resume

\begin{tabular}{|c|c|c|c|c|c|}
\hline No. & ITEM & JUMLAH & LENGKAP & $\begin{array}{c}\text { TIDAK } \\
\text { LENGKAP }\end{array}$ & $\begin{array}{c}\text { PERSENTASE } \\
\text { KELENGKAPAN }(\%)\end{array}$ \\
\hline 1. & $A$ & 18 & 18 & 0 & $100 \%$ \\
\hline 2. & B & 18 & 16 & 2 & $89 \%$ \\
\hline 3. & C & 18 & 18 & 0 & $100 \%$ \\
\hline 4. & D & 18 & 18 & 0 & $100 \%$ \\
\hline 5. & E & 18 & 18 & 0 & $100 \%$ \\
\hline 6. & $\mathrm{~F}$ & 18 & 18 & 0 & $100 \%$ \\
\hline 7. & G & 18 & 18 & 0 & $100 \%$ \\
\hline 8. & $\mathrm{H}$ & 18 & 17 & 1 & $94 \%$ \\
\hline 9. & 1 & 18 & 16 & 2 & $89 \%$ \\
\hline 10. & $\mathrm{~J}$ & 18 & 18 & 0 & $100 \%$ \\
\hline 11. & K & 18 & 16 & 2 & $89 \%$ \\
\hline 12. & L & 18 & 18 & 0 & $100 \%$ \\
\hline 13. & $M$ & 18 & 17 & 1 & $94 \%$ \\
\hline \multicolumn{2}{|c|}{ TOTAL } & 234 & 226 & 8 & $97 \%$ \\
\hline
\end{tabular}
medis pada poin A sampai dengan M dikatakan lengkap dengan kelengkapan pengisian sebesar $98 \%$.

Tabel 4. Data Evaluasi Kelengkapan Resume Medis Pasien Pada Bulan April 2019
Berdasarkan tabel 4 diperoleh perhitungan sebagai berikut :

$\mathrm{P}=\frac{\mathrm{F}}{\mathrm{N}} \times 100 \%$

$\mathrm{P}=\frac{226}{234} \times 100 \%$

$P=0.9658=97 \%$

Hasil perhitungan menurut data KLPCM bulan April 2018, total kelengkapan resume medis pada poin A sampai dengan M dikatakan tidak lengkap dengan kelengkapan pengisian sebesar $97 \%$.

Hasil data kelengkapan resume medis pelayanan kesehatan di Rumah Sakit Delta Surya Sidoarjo diperoleh sebagai berikut:

Tabel 5.Persentase kelengkapan pengisian resume medis bulan Januari-April

\begin{tabular}{cccccc}
\hline No. & BULAN & $\begin{array}{c}\text { JUMLAH } \\
\text { ITEM }\end{array}$ & LENGKAP & $\begin{array}{c}\text { TIDAK } \\
\text { LENGKAP }\end{array}$ & $\begin{array}{c}\text { PERSENTASE } \\
\text { KELENGKAPAN(\%) }\end{array}$ \\
\hline 1. & JANUARI & 221 & 215 & 6 & $97 \%$ \\
2. & FEBRUARI & 234 & 221 & 13 & $94 \%$ \\
3. & MARET & 260 & 251 & 9 & $97 \%$ \\
4. & APRIL & 234 & 226 & 10 & $97 \%$ \\
\hline KELENGKAPAN & 949 & 913 & 38 & $96 \%$ \\
\hline \multicolumn{2}{l}{ PENGISIAN } & 949 & & & \\
\hline
\end{tabular}

Berdasarkan tabel 5 diperoleh perhitungan kelengkapan pengisian resume medis, sebagai berikut:

$\mathrm{P}=\frac{\mathrm{F}}{\mathrm{N}} \times 100 \%$

$\mathrm{P}=\frac{913}{949} \times 100 \%$

$P=0.9620=96 \%$

Berdasarkan data tabel di atas, dihasilkan persentase kelengkapan $97 \%$ pada bulan Januari dan April, 94\% pada bulan Februari, 98\% pada bulan Maret, sehingga persentase kelengkapan bulan Januari - April 2018 yaitu $96 \%$.

Berdasarkan data yang diperoleh, Rumah Sakit Delta Surya Sidoarjo perlu melakukan evaluasi. Tahapan evaluasi yang dilakukan menggunakan program Quality Assurance yang akan dipaparkan sebagai berikut:

A. Perencanaan

Hasil penelitian Quality Assurance langkah pertama yaitu perencanaan di Rumah Sakit Delta Surya Sidoarjo, terdapat beberapa langkah kegiatan yang dihasilkan antara lain 
sebagaiberikut :

Tabel 6. Penilaian perencanaan Quality Assurance

\begin{tabular}{|c|c|c|c|}
\hline \multirow[b]{2}{*}{ No. } & \multirow[b]{2}{*}{ Langkah Quality Assurance } & \multicolumn{2}{|c|}{ Keterisian } \\
\hline & & Sesuai & $\begin{array}{l}\text { Tidak } \\
\text { Sesuai }\end{array}$ \\
\hline 1. & $\begin{array}{l}\text { Menjabarkan program-program dan sasaran } \\
\text { pengisian resume medis ke dalam prosedur } \\
\text { operasional. }\end{array}$ & 1 & 0 \\
\hline 2. & $\begin{array}{l}\text { Berorientasi kuat pada peningkatan mutu } \\
\text { yang ingin dicapai dalam kelengkapan } \\
\text { pengisian resume medis. }\end{array}$ & 1 & 0 \\
\hline 3. & $\begin{array}{l}\text { Melakukan perencanaan strategis mulai } \\
\text { dengan mendefinisikan misi organisasi rekam } \\
\text { medis dalam menunjang kelengkapan } \\
\text { pengisian resume medis. }\end{array}$ & 1 & 0 \\
\hline & Total Kelengkapan & 3 & 0 \\
\hline & Persentase & $100 \%$ & $0 \%$ \\
\hline
\end{tabular}

Berdasarkan tabel 6, diperoleh perhitungan sebagai berikut :

$$
\begin{aligned}
& \mathrm{P}=\frac{\mathrm{F}}{\mathrm{N}} \times 100 \% \\
& \mathrm{P}=\frac{3}{3} \times 100 \% \\
& \mathrm{P}=1=100 \%
\end{aligned}
$$

Berdasarkan hasil perhitungan tentang penilaian perencanaan Quality Assurance, untuk poin lengkap sebesar 3 poin dengan persentase sesuai $100 \%$ dan untuk yang tidak sesuai sebesar $0 \%$, yang diperoleh dari hasil penelitian yang beracuan pada kesesuaian langkah Quality Assurance yang telah dilaksanakan di lapangan.

B. Menyiapkan Pelayanan dan Spesifikasi

Hasil penelitian Quality Assurance berdasarkan langkah kedua yaitu Menyiapkan Pelayanan dan Spesifikasi di Rumah Sakit Delta Surya Sidoarjo, terdapat beberapa langkah kegiatan yang dihasilkan antara lain sebagai berikut:

\begin{tabular}{|c|c|c|c|}
\hline \multirow[b]{2}{*}{ No. } & \multirow[b]{2}{*}{ Langkah Quality Assurance } & \multicolumn{2}{|c|}{ Keterisian } \\
\hline & & Sesuai & $\begin{array}{l}\text { Tidak } \\
\text { Sesuai }\end{array}$ \\
\hline 1. & $\begin{array}{l}\text { Menjabarkan program-program dan sasaran } \\
\text { pengisian resume medis ke dalam prosedur } \\
\text { operasional. }\end{array}$ & 1 & 0 \\
\hline 2. & $\begin{array}{l}\text { Membuat pedoman atau petunjuk praktis } \\
\text { dalam penaisian resume medis. }\end{array}$ & 1 & 0 \\
\hline 3. & $\begin{array}{l}\text { Setiap pasien pulang dari rawat inap akan } \\
\text { diberikan resume medis yang berisi ringkasan } \\
\text { perjalanan penyakit pasien. }\end{array}$ & 1 & 0 \\
\hline 4. & $\begin{array}{l}\text { Pengisian dilakukan segera setelah Dokter } \\
\text { Penanggung Jawab Pasien (DPJP) } \\
\text { memutuskan pasien dapat dipulangkan dan } \\
\text { menokumentasikan di dalam catatan } \\
\text { terintegrasi. }\end{array}$ & 1 & 0 \\
\hline 5. & $\begin{array}{l}\text { Yang harus mengisi resume medis adalah } \\
\text { Dokter Penanggung Jawab Pasien (DPJP) } \\
\text { utama. }\end{array}$ & 1 & 0 \\
\hline 6. & $\begin{array}{l}\text { Dokter Penanggung Jawab Pasien (DPJP) } \\
\text { mengisi resume medis dengan lengkap dan } \\
\text { membubuhkan tanda tangan. }\end{array}$ & 0 & 1 \\
\hline 7. & $\begin{array}{l}\text { Dokter Penanggung Jawab Pasien (DPJP) } \\
\text { mengisis resume medis paling lambat } 1 \times 24 \\
\text { jam sebelum pasien di pulangkan }\end{array}$ & 0 & 1 \\
\hline & Total Kelengkapan & 5 & 2 \\
\hline & Persentase & $71.4 \%$ & $28.6 \%$ \\
\hline
\end{tabular}

Tabel 7. Menyiapakan Pelayanan dan Spesifikasi Quality Assurance

Dilihat dari tabel 7 , diperoleh perhitungan sebagai berikut:

$\mathrm{P}=\frac{\mathrm{F}}{\mathrm{N}} \times 100 \%$

$\mathrm{P}=\frac{5}{7} \times 100 \%$

$\mathrm{P}=0.7142=71.4 \%$

Ketidaksesuaian $=100 \%-71.4 \%=28.6 \%$

Berdasarkan hasil perhitungan tentang penilaian perencanaan Quality Assurance, untuk poin lengkap sebesar 5 poin dengan persentase sesuai $71.4 \%$ dan untuk yang tidak sesuai sebesar 2 poin dengan persentase $28.6 \%$, yang diperoleh dari hasil penelitian yang beracuan pada kesesuaian langkah Quality Assurance yang telah dilaksanakan di lapangan.

C. Mengomunikasikan Pedoman - Pedoman dan Standar

Hasil penelitian Quality Assurance berdasarkan langkah ketiga yaitu Mengomunikasikan Pedoman-Pedoman dan Standar di Rumah Sakit Delta Surya Sidoarjo, terdapat beberapa langkah kegiatan yang dihasilkan antara lain sebagai berikut: 
Tabel 8. Mengomunikasikan Pedoman Pedoman dan Standart Quality Assurance

\begin{tabular}{|c|c|c|c|}
\hline \multirow[b]{2}{*}{ No. } & \multirow[b]{2}{*}{ Langkah Quality Assurance } & \multicolumn{2}{|c|}{ Keterisian } \\
\hline & & Sesuai & $\begin{array}{c}\text { Tidak } \\
\text { Sesuai }\end{array}$ \\
\hline 1. & $\begin{array}{l}\text { Mempromosikan penggunaan standar } \\
\text { operasional prosedur pengisian resume medis } \\
\text { kepada masing-masing petugas kesehatan } \\
\text { atau unit terkait. }\end{array}$ & 1 & 0 \\
\hline 2. & $\begin{array}{l}\text { Penjabaran pedoman penampilan kepada } \\
\text { alat bantu kerja, membuat program pelatihan, } \\
\text { menyelenggarakan konferensi, rapat-rapat, } \\
\text { pertemuan formal/informal, penyajian } \\
\text { prosedur baru, menyediakan on the job } \\
\text { training seperti perubahan-perubahan protokol } \\
\text { administrasi. }\end{array}$ & 1 & 0 \\
\hline & Total Kelengkapan & 2 & 0 \\
\hline & Persentase & $100 \%$ & $0 \%$ \\
\hline
\end{tabular}

Mengacu dari tabel 8, diperoleh perhitungan sebagai berikut:

$$
\begin{aligned}
& P=\frac{F}{N} \times 100 \% \\
& P=\frac{2}{2} \times 100 \% \\
& P=1=100 \%
\end{aligned}
$$

Berdasarkan hasil perhitungan tentang penilaian perencanaan Quality Assurance, untuk poin lengkap sebesar 2 poin dengan persentase sesuai $100 \%$ dan untuk yang tidak sesuai sebesar $0 \%$, yang diperoleh dari hasil penelitian yang beracuan pada kesesuaian langkah Quality Assurance yang telah dilaksanakan dilapangan.

D. Monitoring Mutu

Hasil penelitian Quality Assurance berdasarkan langkah keempat yaitu Monitoring Mutu di Rumah Sakit Delta Surya Sidoarjo, terdapat beberapa langkah kegiatan yang dihasilkan antara lain sebagai berikut:

Tabel 9. Monitoring Mutu Quality Assurance

\begin{tabular}{cccc}
\hline \multirow{2}{*}{ No. } & \multicolumn{2}{c}{ Keterisian } \\
\cline { 3 - 4 } & Sesuai & $\begin{array}{c}\text { Tidak } \\
\text { Sesuai }\end{array}$ \\
\hline 1. & $\begin{array}{l}\text { Menetapkan tingkatan-tingkatan penampilan } \\
\text { resume medis yang dapat di terima dan di } \\
\text { ukur dengn indikator yang telah di tetapkan. }\end{array}$ & 1 & 0 \\
2. $\begin{array}{l}\text { Mendesain suatu sistem untuk mengumpulkan } \\
\text { dan mengkomplain data resume medis. }\end{array}$ & 1 & 0 \\
3. $\begin{array}{l}\text { Menentukan stapa yang mengumpulkan dan } \\
\text { mengolah data serta melaporkan data } \\
\text { kelengkapan resume medis. }\end{array}$ & 1 & 0 \\
4. Pemonitoran kegiatan pengisian resume \\
medis.
\end{tabular}

Berdasarkan table 9, diperoleh perhitungan sebagai berikut:

$$
\begin{aligned}
& P=\frac{F}{N} \times 100 \% \\
& P=\frac{4}{4} \times 100 \% \\
& P=1=100 \%
\end{aligned}
$$

Berdasarkan hasil perhitungan tentang penilaian perencanaan Quality Assurance, untuk poin lengkap sebesar 4 poin dengan persentase sesuai $100 \%$ dan untuk yang tidak sesuai sebesar $0 \%$, yang diperoleh dari hasil penelitian yang beracuan pada kesesuaian langkah Quality Assurance yang telah dilaksanakan di lapangan.

E. Mengidentifikasi Masalah dan Menyeleksi Peluang Untuk Peningkatan

Hasil penelitian Quality Assurance berdasarkan langkah kelima yaitu Mengidentifikasi Masalah dan Menyeleksi Peluang Untuk Peningkatan di Rumah Sakit Delta Surya Sidoarjo, terdapat beberapa langkah kegiatan yang dihasilkan antara lain sebagai berikut:

Tabel 10. Mengidentifikasi Masalah dan Menyeleksi Peluang Untuk Peningkatan Quality Assurance

\begin{tabular}{llc}
\hline \multirow{2}{*}{ No. Langkah Quality Assurance } & Kesuai & $\begin{array}{c}\text { Tidak } \\
\text { Sesuai }\end{array}$ \\
\cline { 2 - 4 } & & 0 \\
\hline 1. $\begin{array}{l}\text { Mengidentifikasi masalah mutu dan mencari } \\
\text { peluang peningkatan dalam pengisian resume } \\
\text { medis. }\end{array}$ & 1 & 0 \\
$\begin{array}{l}\text { 2. Menyeleksi suatu masalah tertentu atas } \\
\text { proses yang difokuskan dalam pengisian } \\
\text { resume medis. }\end{array}$ & 1 & 0 \\
$\begin{array}{l}\text { Melibatkan semua staf yang terkait dalam } \\
\text { upaya meningktkan mutu kelengkapan } \\
\text { pengisian resume medis. }\end{array}$ & 1 & 0 \\
\hline \multicolumn{1}{c}{ Total Kelengkapan } & 3 & $0 \%$ \\
\hline \multicolumn{1}{c}{ Persentase } & $100 \%$ & 0 \\
\hline
\end{tabular}

Dari tabel 10 diperoleh perhitungan sebagai berikut:

$$
\begin{aligned}
& \mathrm{P}=\frac{\mathrm{F}}{\mathrm{N}} \times 100 \% \\
& \mathrm{P}=\frac{3}{3} \times 100 \% \\
& \mathrm{P}=1=100 \%
\end{aligned}
$$

Berdasarkan hasil perhitungan tentang penilaian perencanaan Quality Assurance, untuk poin lengkap sebesar 3 poin dengan persentase sesuai $100 \%$ dan untuk yang tidak sesuai sebesar $0 \%$, diperoleh dari hasil penelitian yang beracuan pada kesesuaian 
langkah Quality Assurance yang telah dilaksanakan di lapangan.

F. Menetapkan Masalah Operasionalnya

Hasil penelitian Quality Assurance berdasarkan langkah keenam yaitu Menetapkan Masalah Operasional di Rumah Sakit Delta Surya Sidoarjo, terdapat beberapa langkah kegiatan yang dihasilkan antara lain sebagaiberikut:

Tabel 11. Menetapkan Masalah Operasional Quality Assurance

\begin{tabular}{|c|c|c|c|}
\hline \multirow[b]{2}{*}{ No. } & \multirow[b]{2}{*}{ Langkah Quality Assurance } & \multicolumn{2}{|c|}{ Keterisian } \\
\hline & & Sesuai & $\begin{array}{l}\text { Tidak } \\
\text { Sesua }\end{array}$ \\
\hline 1. & $\begin{array}{l}\text { Menyatakan secara jelas masalah apa yang di } \\
\text { maksudkan dalam kelengkapan pengisian } \\
\text { resume medis. }\end{array}$ & 1 & 0 \\
\hline 2. & $\begin{array}{l}\text { Menguraikan masalah dengan pertanyaan } \\
\text { meliputi } 4 \mathrm{~W}+1 \mathrm{H} \text {. }\end{array}$ & 1 & 0 \\
\hline 3. & $\begin{array}{l}\text { Menetapkan batasan-batasan masalah agar } \\
\text { tepat sasaran dan tidak meluas. }\end{array}$ & 1 & 0 \\
\hline \multirow[t]{3}{*}{4.} & $\begin{array}{l}\text { Menjamin bahwa statement masalah yang } \\
\text { terjadi dalam pengisian resume medis sudah } \\
\text { jelas. }\end{array}$ & 1 & 0 \\
\hline & Total Kelengkapan & 4 & 0 \\
\hline & Persentase & $100 \%$ & $0 \%$ \\
\hline
\end{tabular}

Dari tabel 11 diperoleh perhitungan

sebagai berikut :

$$
\begin{aligned}
& \mathrm{P}=\frac{\mathrm{F}}{\mathrm{N}} \times 100 \% \\
& \mathrm{P}=\frac{4}{4} \times 100 \% \\
& \mathrm{P}=1=100 \%
\end{aligned}
$$

Berdasarkan hasil perhitungan tentang penilaian perencanaan Quality Assurance, untuk poin lengkap sebesar 4 poin dengan persentase sesuai $100 \%$ dan untuk yang tidak sesuai sebesar $0 \%$, yang diperoleh dari hasil penelitian yang beracuan pada kesesuaian langkah Quality Assurance yang telah dilaksanakan dilapangan.

G. Memilih Tim Identifikasi

Hasil penelitian Quality Assurance berdasarkan langkah ketujuh yaitu Memilih Tim Identifikasi di Rumah Sakit Delta Surya Sidoarjo, terdapat beberapa langkah kegiatan yang dihasilkan antara lain sebagai berikut:

\begin{tabular}{|c|c|c|c|}
\hline \multirow[b]{2}{*}{ No. } & \multirow[b]{2}{*}{ Langkah Quality Assurance } & \multicolumn{2}{|c|}{ Keterisian } \\
\hline & & Sesuai & $\begin{array}{l}\text { Tidak } \\
\text { Sesuai }\end{array}$ \\
\hline & $\begin{array}{l}\text { Mengidentifikasi siapa saja yang terlibat } \\
\text { dalam peningkatan mutu. }\end{array}$ & 1 & 0 \\
\hline 2. & $\begin{array}{l}\text { Menyusun tim untuk mencapai tujuan } \\
\text { menyelesaikan masalah mutu atau } \\
\text { meningkatkan mutu pengisian resume medis. }\end{array}$ & 1 & 0 \\
\hline 3. & $\begin{array}{l}\text { Membuat prosedur kerja tim seperti rapat atau } \\
\text { pertemuan rutin untuk membuat keputusan } \\
\text { dalam mencapai tujuan. }\end{array}$ & 1 & 0 \\
\hline & Total Kelengkapan & 3 & 0 \\
\hline & Persentase & $100 \%$ & $0 \%$ \\
\hline
\end{tabular}

Tabel 12. Memilih Tim Identifikasi Quality Assurance

Perhitungan persentase dari tabel 12 sebagai berikut :

$\mathrm{P}=\frac{\mathrm{F}}{\mathrm{N}} \times 100 \%$

$\mathrm{P}=\frac{3}{3} \times 100 \%$

$\mathrm{P}=1=100 \%$

Berdasarkan hasil perhitungan tentang penilaian perencanaan Quality Assurance, untuk poin lengkap sebesar 3 poin dengan persentase sesuai $100 \%$ dan untuk yang tidak sesuai sebesar $0 \%$, yang diperoleh dari hasil penelitian yang beracuan pada kesesuaian langkah Quality Assurance yang telah dilaksanakan di lapangan.

H. Analisa Masalah dan Identifikasi Penyebab Masalah

Hasil penelitian Quality Assurance berdasarkan langkah kedelapan yaitu Analisa Masalah dan Identifikasi Penyebab Masalah di Rumah Sakit Delta Surya Sidoarjo, terdapat beberapa langkah kegiatan yang dihasilkan antara lain sebagai berikut:

Tabel 13. Analisa Masalah dan Identifikasi

Penyebab Masalah Quality Assurance

\begin{tabular}{llcc}
\hline \multirow{2}{*}{ No. Langkah Quality Assurance } & \multicolumn{2}{c}{ Keterisian } \\
\cline { 3 - 4 } & Sesuai & $\begin{array}{c}\text { Tidak } \\
\text { Sesuai }\end{array}$ \\
\hline 1. $\begin{array}{l}\text { Dalam pengisian resume medis sebelum } \\
\text { mengumpulkan data dan melakukan analisis } \\
\text { perlu adanya statement masalah an klarifikasi } \\
\text { masalah yang terjai. }\end{array}$ & 1 & 0 \\
2. $\begin{array}{l}\text { Memahami terlebih dahulu proses dimana } \\
\text { masalah itu terjadi sehingga menyebabkan } \\
\text { mutu kelengkapan pengisian resume medis } \\
\text { berkurang. }\end{array}$ & 1 & 0 \\
3. $\begin{array}{l}\text { Membuat hipotesa tentang penyebab masalah } \\
\text { dalam pengisian resume medis. }\end{array}$ & 1 & 0 \\
4. Tes hipotesa dan menentukan akar penyebab \\
masalah dalam pengisian resume medis.
\end{tabular}

Tabel 13 menghasilkan perhitungan sebagaiberikut: 


$$
\begin{aligned}
& P=\frac{F}{N} \times 100 \% \\
& P=\frac{4}{4} \times 100 \% \\
& P=1=100 \%
\end{aligned}
$$

Berdasarkan hasil perhitungan tentang penilaian perencanaan Quality Assurance, untuk poin lengkap sebesar 4 poin dengan persentase sesuai $100 \%$ dan untuk yang tidak sesuai sebesar $0 \%$, yang diperoleh dari hasil penelitian yang beracuan pada kesesuaian langkah Quality Assurance yang telah dilaksanakan dilapangan.

I. Membuat Solusi - Solusi dan Kegiatan Kegiatan Untuk Peningkatan Mutu Quality Assurance

Hasil penelitian Quality Assurance berdasarkan langkah kesembilan yaitu Membuat Solusi-Solusi dan Kegiatan-Kegiatan Untuk Peningkatan Mutu di Rumah Sakit Delta Surya Sidoarjo, terdapat beberapa langkah kegiatan yang dihasilkan antara lain sebagai berikut:

Tabel 14. Membuat Solusi-Solusi dan Kegiatan-

Kegiatan Untuk Peningkatan Mutu Quality Assurance

\begin{tabular}{llcc}
\hline \multirow{2}{*}{ No. Langkah Quality Assurance } & \multicolumn{2}{c}{ Keterisian } \\
\cline { 3 - 4 } & Sesuai & $\begin{array}{c}\text { Tidak } \\
\text { Sesuai }\end{array}$ \\
\hline 1. $\begin{array}{l}\text { Mengajak seluruh tim kesehatan yang terkibat } \\
\text { untuk mengeluarkan pendapatnya dalam } \\
\text { meningkatkan mutu kelengkapan resume }\end{array}$ & 1 & 0 \\
$\begin{array}{l}\text { medis. } \\
\text { 2. Menyeleksi kriteria untuk menetapkan solusi } \\
\text { terbaik dalam meningkatkan mutu } \\
\text { kelengkapan resume medis. }\end{array}$ & 1 & 0 \\
$\begin{array}{l}\text { 3. } \\
\text { mereview masing-masing solusi potensial dan }\end{array}$ & 1 & 0 \\
\hline Total Kelengkapan & $\mathbf{3}$ & $\mathbf{0}$ \\
\hline Persentase & $100 \%$ & $\mathbf{0} \%$ \\
\hline
\end{tabular}

Dari tabel 14 diperoleh perhitungan sebagai berikut:

$$
\begin{aligned}
& \mathrm{P}=\frac{\mathrm{F}}{\mathrm{N}} \times 100 \% \\
& \mathrm{P}=\frac{3}{3} \times 100 \% \\
& \mathrm{P}=1=100 \%
\end{aligned}
$$

Berdasarkan hasil perhitungan tentang penilaian perencanaan Quality Assurance, untuk poin lengkap sebesar 3 poin dengan persentase sesuai $100 \%$ dan untuk yang tidak sesuai sebesar $0 \%$, yang diperoleh dari hasil penelitian yang beracuan pada kesesuaian langkah Quality Assurance yang telah dilaksanakan di lapangan.

J. Melaksanakan dan Mengevaluasi Upaya Upaya Peningkatan Mutu

Hasil penelitian Quality Assurance berdasarkan langkah kesepuluh yaitu Melaksanakan dan Mengevaluasi UpayaUpaya Peningkatan Mutu di Rumah Sakit Delta Surya Sidoarjo, terdapat beberapa langkah

\begin{tabular}{|c|c|c|c|}
\hline \multirow[b]{2}{*}{ No. } & \multirow[b]{2}{*}{ Langkah Quality Assurance } & \multicolumn{2}{|c|}{ Keterisian } \\
\hline & & Sesuai & $\begin{array}{l}\text { Tidak } \\
\text { Sesuai }\end{array}$ \\
\hline & $\begin{array}{l}\text { Merencanakan pelaksanaan solusi (plan) } \\
\text { meliputi perencanaan suatu kegiatan dalam } \\
\text { peningkatan mutu pengisian resume medis. }\end{array}$ & 1 & 0 \\
\hline 2. & $\begin{array}{l}\text { Melaksanakan solusi seperti menempatkan } \\
\text { rencana pelaksanaan kedalam kegiatan } \\
\text { peningkatan mutu pengisian resume medis. }\end{array}$ & 1 & 0 \\
\hline & Total Kelengkapan & 2 & 0 \\
\hline & Persentase & $100 \%$ & $0 \%$ \\
\hline
\end{tabular}
kegiatan yang dihasilkan antara lain sebagai berikut:

Tabel 15. Melaksanakan dan Mengevaluasi

Upaya-Upaya Peningkatan Mutu Quality Assurance

Dari tabel 15 diperoleh perhitungan sebagai berikut:

$\mathrm{P}=\frac{\mathrm{F}}{\mathrm{N}} \times 100 \%$

$\mathrm{P}=\frac{2}{2} \times 100 \%$

$\mathrm{P}=1=100 \%$

Berdasarkan hasil perhitungan tentang penilaian perencanaan Quality Assurance, untuk poin lengkap sebesar 2 poin dengan persentase sesuai $100 \%$ dan untuk yang tidak sesuai sebesar $0 \%$, yang di dapatkan dari hasil penelitian yang beracuan pada kesesuaian langkah Quality Assurance yang telah dilaksanakan di lapangan.

\section{KESIMPULAN}

1. Hasil analisis kuantitatif kelengkapan pengisian resume medis pasien di Rumah Sakit Delta Surya Sidoarjo pada bulan Januari-April 2018 diperoleh persentase kesesuaian sebesar $96 \%$.

2. Pengisian resume medis pada Rumah Sakit Delta Surya Sidoarjo dikatakan belum maksimal karena belum dapat mencapai 
angka $100 \%$, sedangkan untuk proses Quality Assurance di Rumah Sakit Delta Surya Sidoarjo diperoleh persentase kesesuaian dalam pelaksanaan kegiatannya mencapai $97,1 \%$.

3. Pengisian resume medis pasien di Rumah Sakit Delta Surya Sidoarjo dipengaruhi oleh ketidaklengkapan pengisian oleh Dokter Penanggung Jawab Pasien (DPJP) dengan tidak dibubuhkannya tanda tangan.

4. Ketentuan pengisian resume medis paling lambat $1 \times 24$ jam sebelum pasien dipulangkan belum terlaksana, sebab fakta di lapangan masih terdapat banyak kolom resume medis yang tidak diisi oleh Dokter Penanggung Jawab Pasien (DPJP).

\section{SARAN}

1. Kepala rekam medis perlu mengadakan pertemuan internal di dalam unit rekam medis untuk meningkatkan kelengkapan pengisian resume medis sesuai dengan Peraturan Direktorat Jenderal Bina Pelayanan Medik Departemen Kesehatan RI Tahun 2008 tentang Standar Pelayanan Minimal Rumah Sakit.

2. Unit rekam medis melakukan pengarahan kepada unit terkait yang bersangkutan untuk melakukan pengisian rekam medis, agar pengisian lembar resume medis lebih ditingkatkan untuk mencapai kelengkapan maksimal yaitu $1 \times 24$ jam sesuai dengan Peraturan Direktorat Jenderal Bina Pelayanan Medik Departemen Kesehatan RI Tahun 2008 tentang Standar Pelayanan Minimal Rumah Sakit.

3. Perlu dibuatkan pedoman mutu untuk meningkatkan mutu Quality Assurance di Rumah Sakit Delta Surya Sidoarjo, tidak hanya untuk unit rekam medis, tetapi untuk unit terkait yang terlibat dalam pengisian rekam medis khususnya lembar resume medis.

4. Unit rekam medis melakukan analisis penyebab masalah dengan melakukan rapat sehingga pedoman mutu QualityAssurance dapat dilaksanakan secara maksimal.

\section{DAFTAR PUSTAKA}

Creswell, J. W. (2010). Research Design: Pendekatan Kualitatif, Kuantitatif, dan Mixed. Yogyakarta: Pustaka Pelajar.

Hatta, G. R. (2014). Pedoman Managemen Informasi Kesehatan di Sarana Pelayanan Kesehatan. Jakarta: Penerbit Universitas Indonesia.

Peraturan Menteri Kesehatan Nomor 129/MENKES/SK/II/2008 tentang Standar Pelayanan Minimal Rumah Sakit.

Peraturan Menteri Kesehatan Nomor 147/MENKES/PER/I/2010 tentang Perizinan Rumah Sakit.

Peraturan Menteri Kesehatan Nomor 269/MENKES/III/2008 tentang Rekam $\mathrm{M}$ e d i s, $\mathrm{P} \mathrm{u} \mathrm{b}$. L . N o. N o . 269/MENKES/III/2008 (2008).

Suryantara, I. G. N. (2015). Merancang Aplikasi Rekam Medis dengan VB.Net. Jakarta: Elex Media Komputindo.

Undang Undang Republik Indonesia No. 44 Tahun 2009 tentang Rumah Sakit.

Undang Undang Republik Indonesia No.29 Tahun 2009 tentang Praktik Kedokteran. 